\title{
APRESENTAÇÃO
}

\section{AS ESCOLAS DO CENTRO PAULA SOUZA NAS PALAVRAS DE SEUS TRABALHADORES EXPRESSÕES DOCENTES EM MEIO A EXPERIÊNCIAS EDUCATIVAS}

\author{
Wenceslao Machado de Oliveira Jr. ${ }^{1}$
}

Nos textos que são publicados nesse número da Revista Linha Mestra pulsam esforços docentes em inventar maneiras de fazer com que o aprendizado se dê de maneiras muito diversas. Pulsa, então, o trabalho do professor como gesto criativo e criador: criativo na medida que mobiliza criativamente materiais, linguagens, tempos e espaços para tornar as experiências discentes mais vivas porque menos rotineiras; criador na medida que cria-se a si mesmo e à educação como matérias vivas, mutantes, em constantes metamorfoses e transformações.

Além disso, pulsam nesses textos as resistências que invadem o trabalho docente. Resistências dos alunos, resistências das coordenações; resistências aos alunos, resistências às coordenações; resistências pelos alunos, resistências pelas coordenações. Resistências que, poderíamos dizer, fazem parte e atuam nos próprios gestos criativos e criadores, os quais se constituem também como ações resistentes, nos múltiplos sentidos que essa expressão pode vir a ter.

Os textos aqui publicados são, em certa medida, desdobramentos de um curso no qual atuei em 2016: "Da prática docente ao artigo científico: caminhos do professor intelectual".

O movimento inicial do curso foi dos próprios docentes, que realizaram e enviaram seus registros de alguma prática docente que consideravam interessante como objeto de reflexão. Nosso primeiro encontro presencial se deu em torno desses registros.

Como modo de disparar "questões mais gerais" acerca daquilo que entendi como sendo uma "ideia de documento" que atravessava os registros enviados pelos professores-cursistas, propus, através do filme Acidente, de Cao Guimarães e Pablo Lobato, a perspectiva do registro acidental. No decorrer da conversa descobri que a "ideia de evidência" era mais intensa que a de documento entre os profissionais do Centro Paula Souza ao produzir e enviar aqueles registros, uma vez que as dinâmicas de gestão da instituição exigia dos professores que produzissem evidências daquilo que realizavam em suas aulas e demais atividades docentes. Nesse sentido, os registros realizados e enviados a mim pelos professores ali presentes eram, sobretudo, evidências de que eles estavam trabalhando... forçando a reflexão sobre eles a lidar também com esse incômodo desassossego em relação às normas de controle institucionais, as quais eram entendidas como normas de cuidado institucionais, por aqueles cujo trabalho vinculava-se às estruturas de gestão.

Descobri assim, que em meio àqueles registros e desejos de escrita que recebi, havia uma tensão latente: as novas estratégias de acompanhamento do trabalho docente eram entendidas, a um só tempo, como controle e cuidado, ainda que os corpos-gestos controlados e cuidados não necessariamente fossem os mesmos. Esses cuidados e controles configuram também inevitáveis resistências que atravessaram nossas conversas e atravessam os textos agora publicados.

Com essas resistências postas em cena, insisti na pergunta: "haveria outras maneiras de fazer-escolher os registros que ativam-participam da reflexão-escrita de um artigo científico, de modo que eles não buscassem evidenciar o acontecido, mas sim já fizessem parte da própria reflexão-escrita?"

\footnotetext{
${ }^{1}$ E-mail: wenceslao.oliveira@gmail.com.
} 
Daí se desdobraram outras questões-conversas em torno do título do próprio curso: 1. o que seria um professor intelectual; 2. o que vem a ser um artigo científico; 3. a "descobertanecessidade" de um "problema" em torno do qual escrever; 4. a complexidade dos "problemas" que atravessam a educação em geral e as práticas docentes em particular.

Nas linhas e entrelinhas de alguns dos textos e imagens aqui publicados noto o esforço de trazer essas perguntas como parte do caminho intelectual do professor, como gesto que perpassa o percurso da prática docente ao artigo científico. Destaco aqui alguns deles: um texto em formato de crônica, algumas coautorias que buscaram formas textuais para estarem juntos, algumas imagens que escapam da mera comprovação de algo, problematizações sutis ou explícitas dos constrangimentos e opacidades que perpassam o trabalho docente.

Os quinze textos desse dossiê compõem duas-três expressões do trabalho no Centro Paula Souza. Duas porque há autores que se expressam como "professores de sala de aula" e autores que se expressam como gestores que, a despeito de seus atuais cargos, seguem expressando a docência em meio a suas outras preocupações e palavras. Três porque entre os textos de professores que atuam em salas de aula há a presença dos dois conjuntos de preocupações docentes que configuram essa instituição: disciplinas comuns ao Ensino Médio e disciplinas técnicas, específicas de um único curso.

Optamos por propor um percurso de leitura que vai do mais específico para o mais geral, das palavras e imagens que remetem às experiências vivenciadas em disciplinas técnicas às experiências vivenciadas na gestão, intermediadas pelas experiências vivenciadas em disciplinas comuns na educação secundária brasileira.

São, portanto, três blocos de textos que configuram dois conjuntos de expressões do trabalho docente realizado no Centro Paula Souza.

O primeiro desses blocos compõem-se dos seguintes textos: “A mudança de hábitos e atitudes para alcançar a estabilidade financeira pessoal e conhecer melhor a questão ambiental”, "Projeto de Arqueologia Simulada desenvolvido na ETEC Gildo Marçal Bezerra Brandão", "Uso de oficinas como prática pedagógica para a assimilação e construção de conceitos", "Uma abordagem diferenciada do direito contratual no Curso Técnico em Administração" e "O trabalho de campo na formação do técnico em Meio Ambiente".

No segundo bloco seguem-se outros cinco textos: "Na contramão, só que não! Reflexões pessoais sobre o uso de ferramentas para auxílio no ensino do componente curricular Biologia para o Ensino Médio", "Um desconhecido entre nós: a História e a Cultura Indígena na sala de aula", "As representações sobre cultura no e do esporte problematizadas no Ensino Médio e Técnico - Ampliando e Aprofundando os Conhecimentos", "Uma aprendizagem significativa para o desenvolvimento da leitura e da escrita" e "Experiência docente com aprendizagem significativa em ETEC".

No terceiro bloco encontram-se os últimos cinco textos do dossiê: "Ação supervisora no planejamento escolar: diretrizes obtidas para a educação profissional de jovens e adultos", "No reverso da conversa com o professor: a questão do PTD", "Ensino técnico em agropecuária no CPS: uma análise da oferta em escolas técnicas estaduais paulistas entre 2012-2016" e "O papel da educação técnica para uma produção mais sustentável" e "Por um Ensino Médio público e plural".

Finalizar o dossiê com um texto-desejo expresso por um dos trabalhadores do Centro Paula Souza acerca do que poderia vir a ser o Ensino Médio brasileiro, propomos que o leitor siga de ouvidos abertos às palavras e aos silêncios que nos chegam das entranhas "de carne e osso e sentimento" das instituições, cotejando o discurso oficial emitido por elas com os ruídos (in)desejáveis emitidos pelos corpos que nela habitam e a constituem.

Despedimo-nos dos leitores, apontando que dos textos aqui publicados nos chegam sensações de que o trabalho docente é atravessado por emoções e pressões variadas, por 
disposições em fazer e registrar, por ritmos e percursos muito distintos, mas sobretudo nos chegam sensações de que o trabalho docente é atravessado pelo desejo de composição com o "outro" diante do professor. Um "outro" que, apesar de múltiplo - materiais agenciados, ritmos experimentados, locais visitados, autores citados, poderes disputados etc -, se configura sempre em meio ao "grande outro" dos profissionais da educação: os alunos.

Por isso mesmo eles foram chamados a compor esse dossiê e aceitaram o convite. Suas produções, em variadas linguagens, podem ser lidas, vistas e ouvidas no material anexo ao final. 